\section{Rowcovers Improve Winter Survival and Production of Western Trailing 'Siskiyou' Blackberry in the Eastern United States}

\author{
Fumiomi Takeda ${ }^{1,7}$, Kathy Demchak ${ }^{2}$, Michele R. Warmund ${ }^{3}$, \\ David T. Handley ${ }^{4}$, Rebecca Grube ${ }^{5}$, and Charles Feldhake ${ }^{6}$
}

AdDITIONAL INDEX WORDs. Rubus, trellis, primocane, floricane, fruit, yield, protected cultivation, temperature, humidity, vapor pressure deficit, water content

SUMMARY. Winter injury has limited the expansion of commercial blackberry (Genus $R u b u s$, subgenus $R u b u s$ ) production into more northern latitudes in central and eastern United States. Rowcover (RC) was applied over trailing 'Boysenberry' and 'Siskiyou' and erect, thornless 'Triple Crown' and 'Apache' blackberries at Kearneysville, WV (lat. $39.5^{\circ} \mathrm{N}$, USDA Plant Hardiness Zone 6b) from 2004 to 2007. The daily minimum temperatures under $\mathrm{RC}$ were as much as $5^{\circ} \mathrm{F}$ to $10^{\circ} \mathrm{F}$ higher at nights after sunny days, but were similar during nights after overcast days. On sunny days, daily maximum temperatures under $\mathrm{RC}$ were as much as $28{ }^{\circ} \mathrm{F}$ higher than in the open. Under RC, humidity rose more quickly and remained higher during the day than in the open, but was slightly lower at night. Mean vapor pressure deficit in late December, January, February, and early March was 100 to $250 \mathrm{kPa}$ higher under RC than in the open. RC treatment significantly reduced winter injury and increased yield in 'Siskiyou' blackberry plants. The winter protection techniques described here would provide substantial benefits for growing blackberries in more northern areas where winter injury frequently causes crop failure.

$\mathrm{B}$ lackberry production for the fresh fruit market has grown in the United States. Commercial acreage has expanded, most notably in California (M. Jimenez, personal communication) and Georgia (G. Krewer, personal communication). However, blackberry production is low in areas where sub-zero Fahrenheit temperatures are common during the winter (U.S. Department of Agriculture, 2004). Current

The authors thank Ann Hummell Rose, Scott Wolford, and Sharon Jones for their technical assistance and for carrying out this research.

${ }^{1}$ Research Horticulturist, Appalachian Fruit Research Station, U.S. Department of Agriculture, Agricultural Research Service, 2217 Wiltshire Road, Kearneysville, WV 25430

${ }^{2}$ Senior Extension Associate, Department of Horticulture, 107A Tyson Building, Pennsylvania State University, University Park, PA 16802

${ }^{3}$ Professor, Department of Crop Sciences, University of Missouri, Columbia, MO 65211

${ }^{4}$ Extension Specialist, University of Maine Cooperative Extension, Highmoor Farm, P.O. Box 179, Monmouth, ME 04259

${ }^{5}$ Assistant Professor, Department of Plant Biology, Rudham Hall, University of New Hampshire, Durham, NH 03824

${ }^{6}$ Soil Scientist, Appalachian Farming Systems Research Center, U.S. Department of Agriculture, Agricultural Research Service, 1224 Airport Road, Beaver, WV 25813

${ }^{7}$ Corresponding author. E-mail: Fumi.Takeda@ars. usda.gov commercial blackberry cultivars are not adapted to winter temperatures below $-13{ }^{\circ} \mathrm{F}$, and this has limited the expansion of commercial blackberry production into states in northeastern and midwestern United States. In these areas, however, the interest in growing blackberries remains high among small and part-time farmers looking for crops with a market niche and the potential for high returns on their investment.

Warmund et al. (1992) reported that in mid-winter when buds have reached their maximum hardiness, flower buds of eastern thornless blackberries are killed at $-9{ }^{\circ} \mathrm{F}$. In controlled freezing studies, Cortell and Strik (1997) reported canes and buds of western trailing 'Marion' blackberry survived temperatures as low as $-9^{\circ} \mathrm{F}$ in one year, but only to $16{ }^{\circ} \mathrm{F}$ in another year. In the field, floral buds of 'Marion' blackberry often suffer winter injury when temperatures drop below $12{ }^{\circ} \mathrm{F}$ (Crandall, 1995), and plants quickly deacclimate to cold temperatures once their dormancy or rest requirement has been fulfilled (Bell et al., 1995). The loss of cold hardiness in some winters may be related to the warm weather that precedes extremely low temperatures. In Oregon, 'Siskiyou', another western trailing blackberry, did not show visible injuries after a winter in which temperatures dropped to $10{ }^{\circ} \mathrm{F}$ on several nights (Finn et al., 1999). However, 'Siskiyou' has not produced a crop in the upper Piedmont region of North Carolina (USDA Plant Hardiness Zone $7 \mathrm{~b}$ ) where fluctuating temperatures in winter are common (J. Ballington, personal communication).

For blackberry production to expand into colder midwestern and northeastern United States, cultivars with increased winterhardiness or systems to protect blackberry plants from winter injury are needed. Improved trellis design and canetraining techniques that improve winter-protection strategies, but also result in improved harvest efficiency, would enable diversification for small farms and would open up niche markets for alternative products. Modifications of the crop environment and production techniques could decrease weather-related stresses and desiccation injury. Kozlowski (1976) stated that such injury occurs when a large vapor pressure deficit or solar radiation load at low temperatures results in a rate of water loss from aboveground parts of the plant that exceeds the rate of water uptake and transport from the roots. Energyconservation methods, such as using

\begin{tabular}{llll}
\hline $\begin{array}{l}\text { Units } \\
\begin{array}{l}\text { To convert U.S. to SI, } \\
\text { multiply by }\end{array}\end{array}$ & U.S unit & SI unit & $\begin{array}{l}\text { To convert SI to U.S., } \\
\text { multiply by }\end{array}$ \\
\hline 0.4047 & $\mathrm{acre}(\mathrm{s})$ & $\mathrm{ha}$ & $2.471 \mathrm{l}$ \\
100 & $\mathrm{bar}$ & $\mathrm{kPa}$ & 0.01 \\
0.3048 & $\mathrm{ft}$ & $\mathrm{m}$ & 3.2808 \\
2.54 & inch(es) & $\mathrm{cm}$ & 0.3937 \\
25.4 & inch(es) & $\mathrm{mm}$ & 0.0394 \\
0.4536 & $\mathrm{lb}$ & $\mathrm{kg}$ & 2.2046 \\
0.0254 & $\mathrm{mil}$ & $\mathrm{mm}$ & 39.3701 \\
28.3495 & $\mathrm{Oz}$ & $\mathrm{g}$ & 0.0353 \\
33.9057 & $\mathrm{Oz} / \mathrm{yard}^{2}$ & $\mathrm{~g} \cdot \mathrm{m}^{-2}$ & 0.0295 \\
$\left({ }^{\circ} \mathrm{F}-32\right) \div 1.8$ & ${ }^{\circ} \mathrm{F}$ & ${ }^{\circ} \mathrm{C}$ & $\left(1.8 \times{ }^{\circ} \mathrm{C}\right)+32$ \\
& & &
\end{tabular}


rowcovers (RC), reducing radiation cooling, and minimizing the vapor pressure deficit (VPD), reduce the loss of water vapor out of the plant (Hanan, 1998; Kramer, 1983). A wide variety of techniques, such as RC, coldframes, plasticulture, plasticcovered and glass greenhouses, and high tunnels (HT), have been used to modify the environment for vegetable (Lamont, 2005) and berry crops (Pritts et al., 1999), and extend their production season. In addition to modifying soil and air temperatures, these techniques also protect plants from wind damage and may limit pests.

Intensive protected crop production methods that integrate plastic mulch, HT, and RC circumvent climate-imposed limitations to crop production (Wells and Loy, 1985). At the Appalachian Fruit Research Station in Kearneysville, WV, a novel trellis system called the rotatable cross arm (RCA) trellis resulted in a compatible cane-training technique to aid mechanical harvesting of fresh market quality fruit of eastern thornless blackberries (Harper et al., 1999; Takeda and Peterson, 1999). The RCA trellis design is similar to the shift trellis system described by Stiles (1999). The RCA system has a short upright post with a long cross-arm at the top of the post that rotates as much as $180^{\circ}$ (Takeda and Peterson, 1999; Takeda et al., 2003) (Fig. 1). The cane training technique developed for this trellis system (Takeda, 2008), separates the floricanes and primocanes on the trellis and completes much of primocane training before the fruit matures. In the fall, floricanes with their lateral canes tied to the wires may be inclined to a horizontal position and placed close to the ground by rotating the cross arms. Inclination of the lateral canes close to the ground creates a plant shape conducive to the placement of winter protection material over the plant. In spring, the cover is removed. After flowering shoots emerge from buds on the lateral canes and grow vertically, and the cross-arms can be rotated through the vertical and an additional $30^{\circ}$ so that much of the fruit hangs on one side of a narrow canopy below the cross arm. The erect and trailing blackberries are adapted to canopy manipulation and for primocane training on the RCA

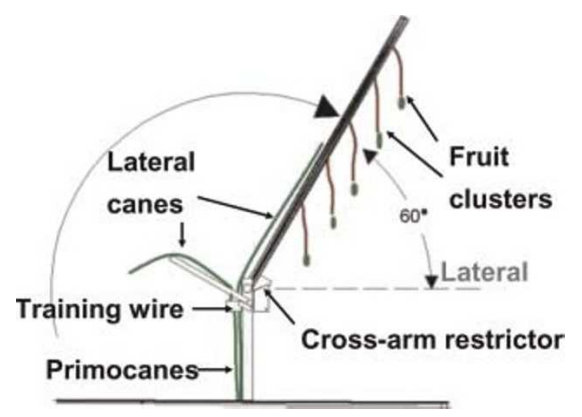

Fig. 1. A schematic drawing of the blackberry plants trained to the rotatable cross-arm (RCA) with the cross-arms positioned for harvest. Note that the cross-arms were lifted from their winter position, close to the ground, to a vertical position and an additional $30^{\circ}$ so that fruit clusters hung down. With the cross-arm rotated beyond the vertical, the new primocanes arising from the crown could be manipulated onto the training wire near the top of the post.

trellis. Based on these findings, we hypothesized that the RCA trellis and cane training system could provide a practical technique for growing and protecting blackberries from winter injury by laying RC over blackberry plants that are low to the ground. The objective of this study was to determine the effect of different winter cover treatments on the productivity of field-planted erect and trailing blackberries trained to the RCA trellis.

\section{Materials and methods}

Nursery-mature 'Apache', 'Boysenberry', 'Siskiyou', and 'Triple Crown' transplants were established on raised beds, covered with black landscape fabric at the Appalachian Fruit Research Station, Kearneysville, WV (lat. $39.5^{\circ} \mathrm{N}, 550 \mathrm{ft}$ elevation, USDA Plant Hardiness Zone 6b) in Spring 2001. Rows were spaced $11 \mathrm{ft}$ apart and were oriented in the northsouth direction with an interrow spacing of $5 \mathrm{ft}$ between plants. Plot maintenance and pest control followed the established bramble production guidelines for the region (Brittingham-Brant et al., 2006). A modified RCA trellis was installed in Fall 2001. The description of the RCA trellis and the sequence of primocane training and positioning of the cross arms are reported elsewhere (Takeda, 2008; Takeda et al., 2003). During May and June, three to five primocanes were bent and tied to the training wire 20 inches off the ground when they were about 30 inches tall. Primocanes were tipped when they reached the adjacent plant. Lateremerging primocanes were removed before they were $2 \mathrm{ft}$ tall. Lateral canes that emerged from axillary buds on the tied canes were restricted to the angle created by the wires on the main, rotatable arm and a movable short arm on the other side of the post (Fig. 1). Lateral canes were tipped when they were about $5 \mathrm{ft}$ long. Floricanes were pruned after the harvest was complete. In late November, the cross arm was rotated perpendicularly away from the harvest position and downward so that the tip of the cross arm touched the ground (Fig. 2 ). Rotation of cross-arms positioned all canes at the height of the pivot point for the cross-arm at the top of the trellis post or closer to the ground and allowed application of RC. Crossarms remained in the horizontal position until the flowering laterals emerged from the axillary buds on the tied canes and began to grow upward. Once bloom occurred, the cross-arm was rotated through the vertical and an additional $30^{\circ}$ to a harvest position where it rested on the cross-arm restrictor (Fig. 1).

For the 2004-05 season, plants of all four cultivars were left in the open or were covered with $1.5-\mathrm{oz} /$ yard $^{2}$ RC (Grow Guard 51; Atmore Industries, Atmore, AL) alone or with $\mathrm{RC}$ and 4-mil clear polyethylene (PE)

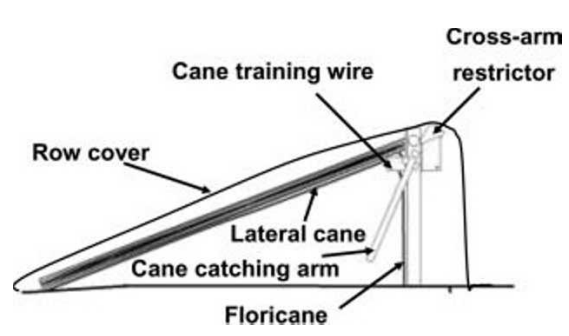

Fig. 2. A schematic drawing of the rotatable cross-arm trellis system in its winter position covered with rowcover. Lateral canes that emerged from the horizontally growing portion of primocanes were tied to the wires on the cross-arm. The short cross-arm is shown in the down position. After the rotation of the main cross-arm to its harvest position, the short arm is raised so that the wire catches lateral canes growing outward, as shown in Fig. 1 . 
sheeting $(\mathrm{RC}+\mathrm{PE})$ (Covalence Plastics, Minneapolis, MN) (Fig. 2). The edges of these covers were secured to the ground by placing bags filled with stones at $\approx 4$ - $\mathrm{ft}$ intervals and laying 5-ft-long metal pipes on top of RC at $\approx 10$-ft intervals. Treatments in 2005-06 and 2006-07 were applied only to 'Siskiyou' plants. In 2005-06, winter protection treatments were one or two layers of RC (Grow Guard $51)$ and no coverover plants. In 2004-05 and 2005-06, RC treatments remained in place from early December to early March. In 200607 , plants were covered with one layer of RC (Grow Guard 5l) or had no cover. In that season, plants were covered from early Dec. 2006 to mid-Mar. 2007, but one side remained open at $1 \mathrm{ft}$ above the ground for ventilation until 16 Jan. 2007.

Data loggers (WatchDog ${ }^{\circledR}$ Model 125; Spectrum Technologies, Plainfield, IL) recorded temperatures in each plot at $10-\mathrm{min}$ intervals from early December to mid-March in the 2004-05 and 2005-06 studies. From December to March, external temperature sensors (Spectrum Technologies) recorded air temperatures at a 15-inch height above ground, and soil temperatures at a 6-inch depth. Data loggers with temperature and humidity sensors (WatchDog ${ }^{\circledR}$ Model 150) recorded temperatures and relative humidity at 10 -min intervals from December to March in the 2006-07 study. All sensors used to record air temperature and humidity were encased in radiation shields (Spectrum Technologies). Using temperature and relative humidity recordings, hourly VPD was calculated according to Richards (1971) for plots in the open and under RC.

In Spring 2005, cane dieback was determined. Canes were sectioned at 4 -inch increments from the distal end to green tissue. The date when the first flower opened on each plant was recorded. In early June, the number of nodes and flowering shoots on 10 lateral canes per plant were counted. For the 2006-07 study, 'Siskiyou' cane samples were collected in December, January, and February, and 2 -inch sections were weighed and reweighed after $72 \mathrm{~h}$ in a drying oven (at $140^{\circ} \mathrm{F}$ ) to determine water content.

Controlled freezing tests determined the low temperature suscep- tibility of 'Siskiyou' buds. Tissue for freezing tests was collected on 27 Nov. 2006, 31 Jan. 2007, and 6 Mar. 2007. Because there was extensive cane damage in the early spring, tissue was sampled only from plants under RC on 6 Mar. 2007. On each sampling date, six four-node cuttings were collected from the middle portion of 5 - $\mathrm{ft}$ lateral canes on the RCA trellis. Tissue was then sealed in PE bags, packed on ice, and sent by overnight mail to the University of Missouri, Columbia, where freezing tests were conducted. Immediately after the receipt of the tissue, a fournode cane sample was placed in moist cheesecloth and wrapped in aluminum foil. A 0.01-mm-diameter (30gauge) copper constantan thermocouple was placed in contact with a sample bud enclosed in aluminum foil to monitor tissue temperature. Thermocouple output was read with a digital thermometer (Omega Engineering, Stamford, CT). Samples were placed in a programmable freezer at $28{ }^{\circ} \mathrm{F}$ and held at this temperature for $1 \mathrm{~h}$. The cheesecloth froze and seeded the tissue with ice at about $30^{\circ} \mathrm{F}$. Samples were cooled at $3{ }^{\circ} \mathrm{C}$ per hour and removed from the freezer at hourly intervals at tissue temperatures that were estimated to result in bud injury, and thawed at $36^{\circ} \mathrm{F}$ for $24 \mathrm{~h}$. After thawing, tissue was incubated at $100 \%$ relative humidity and $75{ }^{\circ} \mathrm{F}$ for $5 \mathrm{~d}$, sectioned with a razor blade, and examined for oxidative browning under a dissecting microscope at $\leq 40 \times$ magnification. The number of injured and uninjured axillary buds was recorded and the modified Spearman-Karber equation as described by Bittenbender and Howell (1974) was used to calculate the temperature at which $50 \%$ of buds was injured $\left(\mathrm{LT}_{50}\right)$ at each sampling date.

Fruit were harvested in June and July. Twenty mature primary (terminal fruit of each cluster and secondary fruit that developed on lateral pedicels of each cluster) (Takeda, 1987) fruit were harvested weekly from each plant and were weighed individually. Subsequently, fruiting shoots were harvested and counts of primary and secondary fruit were taken. In addition, where fruit had matured and abscised, the pedicles were counted. Plant yield was estimated as follows: Yield $(\mathrm{lb} /$ plant $)=[$ (no. primary fruit $\times$ average weight of primary fruit $)+($ no. secondary fruit $x$ average weight of secondary fruit) $] \times$ (no. fruit clusters per lateral cane $) \times($ no. lateral canes per plant).

The experiment was a randomized complete-block experimental design for each cultivar with two sixplant replications in the 2004-05 season and four four-plant replications in the 2005-06 and 2006-07 seasons. Percentage data were transformed to square root-arcsin before statistical analysis. Reproductive and vegetative data were subjected to an analysis of variance using the PROC GLM procedures (SAS Institute, Cary, NC). Statistical significance was evaluated at $P \leq 0.05$.

\section{Results and discussion}

Covered and unprotected 'Apache' and 'Triple Crown' plants showed little bud damage and produced $\approx 25 \mathrm{lb}$ of fruit per plant, similar to yields obtained from plants established in 1998 (data not presented); hence, winter protection treatments were not applied to these cultivars in 2005 or 2006. Buds of eastern thornless blackberries were reported to exhibit low temperature exotherms around $-9{ }^{\circ} \mathrm{F}$ (Warmund et al., 1992). Minimum daily temperatures remained above $3{ }^{\circ} \mathrm{F}$ during Winter 2004-05. Normally erect blackberry cultivars do not show winter damage until temperatures drop below $-4{ }^{\circ} \mathrm{F}$ (M.R. Warmund, unpublished data). Western trailing 'Boysenberry' plants produced primocanes less than $5 \mathrm{ft}$ tall and few, short lateral canes (data not presented). Winter injury was extensive in covered 'Boysenberry' plants and those grown in the open. In Spring 2005 , all lateral canes and many of the main canes, tied at 2-ft height, were dry and brittle. On 'Boysenberry' plants that were under RC in winter, some flowering shoots developed on cane sections near the ground, but the fruit were soft or shriveled at maturity. Consequently, the RC treatment on 'Boysenberry' was ended for the study after the first year. 'Siskiyou' plants, however, grew vigorously in 2004,2005, 2006, and 2007 , producing three to five primocanes in May and June. As many as nine lateral shoots developed from axillary buds along the horizontal part of main canes. Many lateral canes 
were $5 \mathrm{ft}$ long with 35 to 40 nodes by late summer.

During Winter 2004-05, 'Siskiyou' plants protected with RC and $\mathrm{RC}+\mathrm{PE}$ had significantly less cane and bud injury than unprotected plants, but this was highly variable among canes (Fig. 3, A and B). Flowering shoots emerged from only $4 \%$ of the axillary buds on unprotected plants, whereas shoots developed from $40 \%$ and $80 \%$ of buds on plants covered with $\mathrm{RC}$ alone and $\mathrm{RC}+\mathrm{PE}$ (Table 1). In 2005, 'Siskiyou' plants covered with RC and RC + PE in winter began flowering 7 and $11 \mathrm{~d}$ earlier than plants in the open. Fruit harvest on winter-protected 'Siskiyou' plants began on June 20. Plants under RC produced $\geq 5.5 \mathrm{lb}$ more fruit per plant than plants that were not covered.

RC-covered 'Siskiyou' plants produced significantly more fruit than plants in the open in 2006 and 2007 (Table 2). Fruit cluster number per plant increased from 171 on plants in the open to more than 320 on plants protected with RC in winter. Plants protected with RC in winter produced significantly larger primary berries. Plants in the open yielded $5.7 \mathrm{lb}$ per plant, whereas plants protected with one and two layers of RC produced 12.8 and $14.1 \mathrm{lb}$ of fruit per plant, respectively, in 2006. In 2007, plants that were protected in winter produced more than 320 fruit clusters compared with less than 100 on plants in the open. Primary fruit were slightly heavier on plants protected in winter than on plants in the open, but secondary fruit weight was similar. In 2007 , protected plants produced $12.1 \mathrm{lb}$ of fruit per plant or 2.6 times more fruit than plants in the open.

From Dec. 2004 to Feb. 2005, maximum daytime temperatures under RC and RC + PE covers reached up to $85^{\circ} \mathrm{F}$ and were $20^{\circ} \mathrm{F}$ to $27^{\circ} \mathrm{F}$ higher than in the open (Fig. 4). Usually higher temperatures were recorded under $\mathrm{RC}+\mathrm{PE}$ than under $\mathrm{RC}$ alone. The high temperature at that time of year is a concern because it may induce bud growth and early budbreak. At night, there were periods when the minimum temperature was $7^{\circ} \mathrm{F}$ lower in the open than under RC and RC + PE. In late Jan. 2005, temperatures below $10^{\circ} \mathrm{F}$ occurred on several nights in the open and
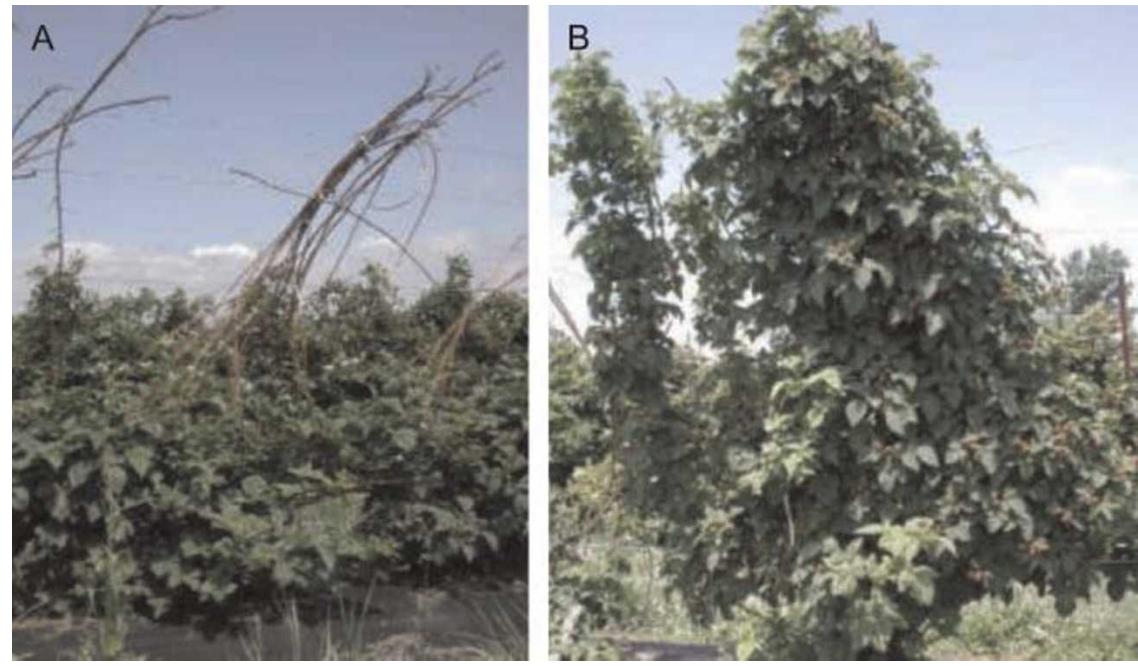

Fig. 3. 'Siskiyou' blackberry plants in spring. (A) 'Siskiyou' plants not protected in winter. Note that spring growth is absent on lateral canes. (B) 'Siskiyou' plants protected with floating rowcover (RC) in winter. Note that many shoots have emerged from axillary buds on the entire length of lateral canes.

Table 1. Cane and bud survival, initial bloom date, and yield of 'Siskiyou' trailing blackberry plants in 2005 in the open (Open), covered with one layer of floating rowcover (RC), or covered with $\mathrm{RC}$ and polyethylene sheet (RC + PE) from Dec. 2004 to Feb. 2005.

\begin{tabular}{|c|c|c|c|c|}
\hline \multirow{2}{*}{$\begin{array}{l}\text { Cover } \\
\text { treatment }\end{array}$} & \multicolumn{2}{|c|}{ Alive (\%) } & \multirow{2}{*}{$\begin{array}{c}\text { Initial } \\
\text { bloom date }\end{array}$} & \multirow{2}{*}{$\begin{array}{c}\text { Yield } \\
(1 \mathrm{~b} / \text { plant })^{\mathrm{y}}\end{array}$} \\
\hline & Cane & $\overline{B u d}$ & & \\
\hline Open & $19 \mathrm{~b}^{\mathrm{z}}$ & $4 \mathrm{~b}$ & 22 May a & $2.9 \mathrm{~b}$ \\
\hline $\mathrm{RC}$ & $56 \mathrm{a}$ & $40 \mathrm{a}$ & 15 May b & $10.6 \mathrm{a}$ \\
\hline $\mathrm{RC}+\mathrm{PE}$ & $86 \mathrm{a}$ & $80 \mathrm{a}$ & 11 May c & $8.6 \mathrm{a}$ \\
\hline
\end{tabular}

${ }^{\mathrm{z}}$ Means within a column followed by the same letter are not significantly different at $P=0.05$. ${ }^{\mathrm{l}} \mathrm{l} \mathrm{lb}=0.4536 \mathrm{~kg}$.

Table 2. Effects of rowcover (RC) application on fruit clusters per plant, fruit per cluster, fruit weight, and plant yield in 'Siskiyou' blackberry in 2006 and 2007. Plants were covered with one layer of RC (1X), two layers of RC (2X), or left uncovered (Open).

\begin{tabular}{|c|c|c|c|c|c|}
\hline \multirow[b]{2}{*}{ Rowcover } & \multirow{2}{*}{$\begin{array}{l}\text { Fruit clusters } \\
\text { (no./plant) }\end{array}$} & \multirow{2}{*}{$\begin{array}{c}\text { Fruit } \\
\text { (no./cluster) }\end{array}$} & \multicolumn{2}{|c|}{ Fruit wt (g/fruit) $)^{\mathrm{z}}$} & \multirow{2}{*}{$\begin{array}{c}\text { Yield } \\
(1 \mathrm{~b} / \text { plant })^{\mathrm{z}} \\
\end{array}$} \\
\hline & & & Primary & Secondary & \\
\hline \multicolumn{6}{|l|}{$2005-06$} \\
\hline Open & $171 b^{y}$ & $2.7 \mathrm{a}$ & $5.3 \mathrm{~b}$ & $3.1 \mathrm{a}$ & $5.7 \mathrm{~b}$ \\
\hline $1 \mathrm{X}$ & $322 \mathrm{a}$ & $2.6 \mathrm{a}$ & $8.3 \mathrm{a}$ & $4.8 \mathrm{a}$ & $12.8 \mathrm{a}$ \\
\hline $2 \mathrm{X}$ & $350 \mathrm{a}$ & $3.1 \mathrm{a}$ & $8.5 \mathrm{a}$ & $5.0 \mathrm{a}$ & $14.1 \mathrm{a}$ \\
\hline \multicolumn{6}{|l|}{$2000-07$} \\
\hline Open & $96 \mathrm{~b}$ & $-^{\mathrm{x}}$ & $7.2 \mathrm{a}$ & $6.3 \mathrm{a}$ & $4.6 \mathrm{~b}$ \\
\hline $1 \mathrm{X}$ & $325 \mathrm{a}$ & 一 & $8.0 \mathrm{~b}$ & $6.3 \mathrm{a}$ & $12.1 \mathrm{a}$ \\
\hline
\end{tabular}

${ }^{\mathrm{z}} \mathrm{lg}=0.0353 \mathrm{oz}, \mathrm{l} \mathrm{lb}=0.4536 \mathrm{~kg}$.

y Means within a column and within year followed by the same letter are not significantly different at $P=0.05$. No data.

under RC treatment, but not under $\mathrm{RC}+\mathrm{PE}$. Soil temperatures under RC and $\mathrm{RC}+\mathrm{PE}$ treatments remained above $32^{\circ} \mathrm{F}$ during the winter, but in the open, soil temperatures remained below $32^{\circ} \mathrm{F}$ for about 3 weeks from 18 Jan. to 6 Feb. 2005 (Fig. 5). Although not part of this study, soil temperatures recorded during Winter 2007-08 also showed that the tem- peratures at 3 -inch depth in open plots were at or slightly below $32^{\circ} \mathrm{F}$ in late January compared with about $34^{\circ} \mathrm{F}$ in RC-covered plots (data not presented).

The pattern of temperatures recorded during Winter 2005-06 (Fig. 6) was different from that recorded the previous winter (Fig. 4). The temperatures in Jan. 2006 were 


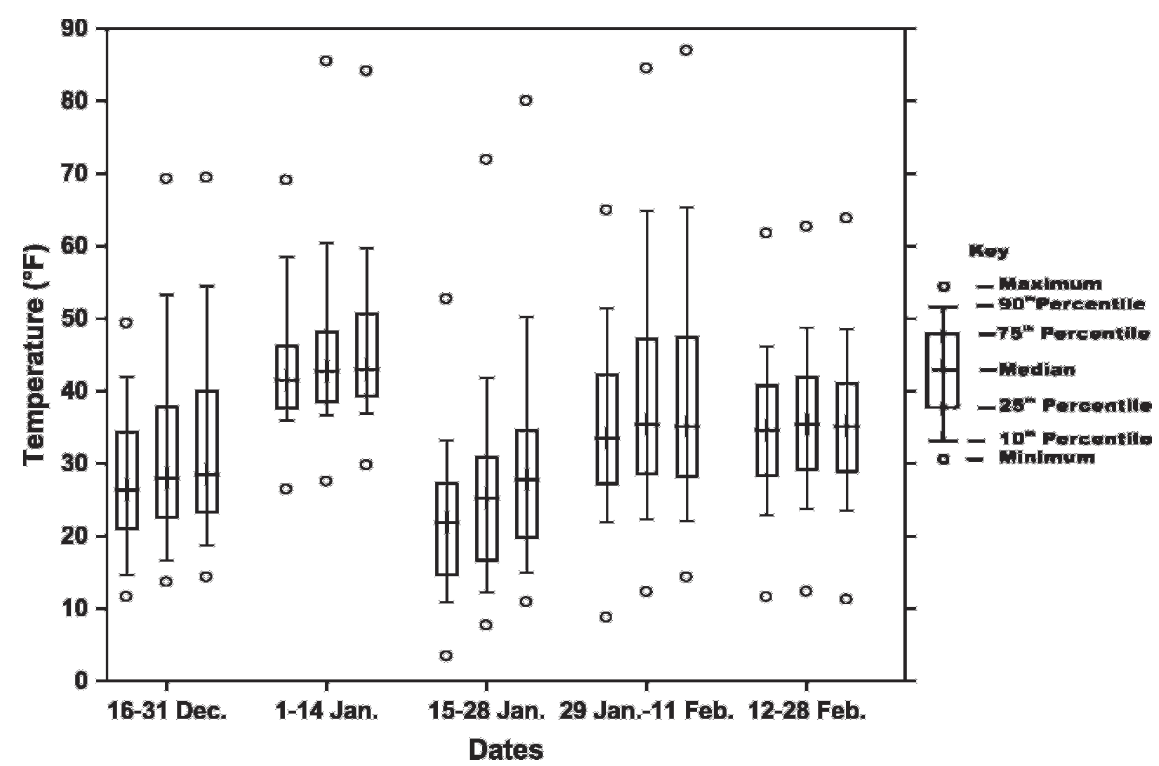

Fig. 4. Box-and-whisker plots showing the seasonality and extent of temperature variations in the open- and underwinter protection covers during Winter 2004-05. Top and bottom sides of the box represent the 75th and 25th percentiles of temperatures recorded for the period, respectively. Whiskers at the top and bottom of the box represent 90 th and 10th percentiles of temperatures recorded for the period, respectively, and the circles at the top and bottom sides represent the maximum and minimum temperatures recorded for the period. Three plots in each period represent temperatures recorded in the open, under floating rowcover, and floating rowcover plus plastic, respectively; $\left({ }^{\circ} \mathrm{F}-32\right) \div 1.8={ }^{\circ} \mathrm{C}$.

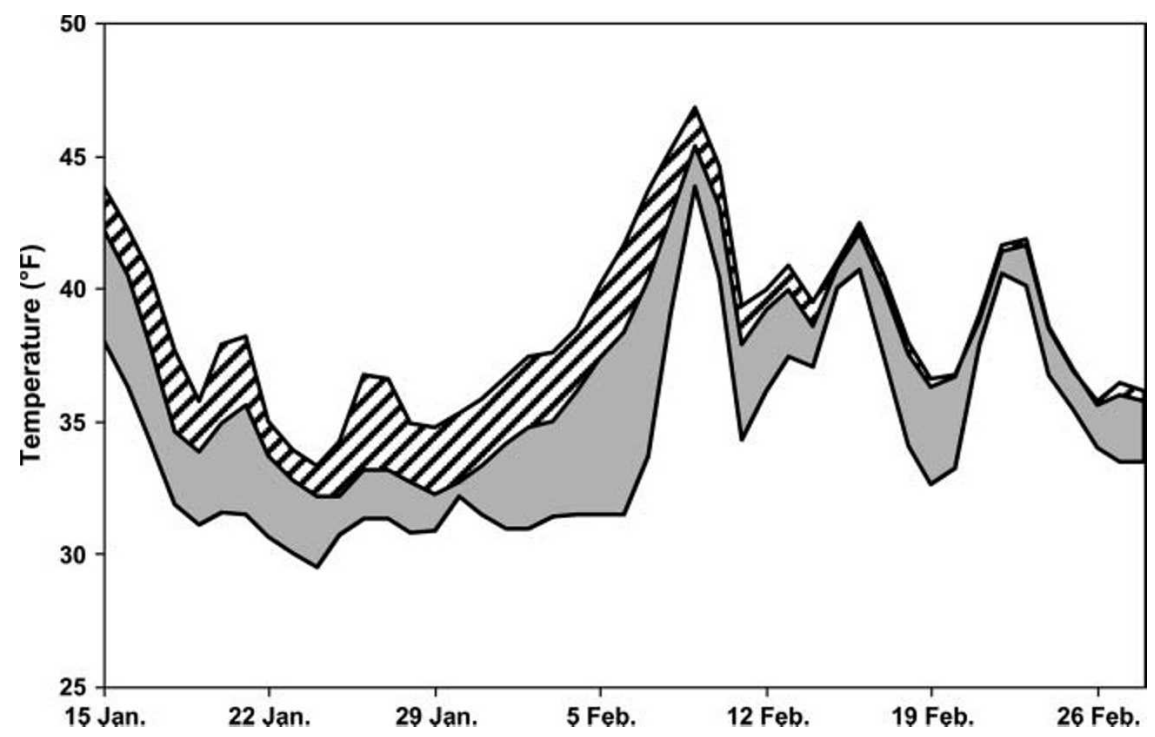

Fig. 5. Average daily soil temperatures during Jan. and Feb. 2005. Temperature probes were installed at a 6 -inch $(15.2 \mathrm{~cm})$ depth in the center of raised beds covered with weed barrier fabric. Soil in the open (bottom line), soil under floating rowcover (middle line), and soil under floating rowcover plus plastic sheet (top line $) ;\left({ }^{\circ} \mathrm{F}-32\right) \div 1.8={ }^{\circ} \mathrm{C}$.

higher compared with Jan. 2005. Throughout Winter 2005-06 winter, temperatures under one and two layers of $\mathrm{RC}$ were generally higher than in the open, however, temperature differences between one and two layers of $\mathrm{RC}$ were small. Temperatures in the open fell below $5^{\circ} \mathrm{F}$ one night in early December and again in late February, but, under covers, the temperatures did not fall below $10^{\circ} \mathrm{F}$ (Fig. 6).

In Winter 2006-07, temperatures remained relatively mild until mid-January (Fig. 7), with daily mean temperatures above $30{ }^{\circ} \mathrm{F}$ and the minimum temperatures remaining above $15^{\circ} \mathrm{F}$ at night. For these reasons, one side of the RC remained open for ventilation until 16 Jan. From mid-December to mid-January, when one side of the RC was vented, the median temperatures under the $\mathrm{RC}$ and in the open were similar, but temperature extremes were greater under the RC. From 16 Jan. to lateFeb., when both sides of the RC were secured to the ground, the mean daily temperatures under the $\mathrm{RC}$ were higher than in the open by $5^{\circ} \mathrm{F}$, and for short periods during sunny days the temperatures under the RC were more than $20^{\circ} \mathrm{F}$ higher than in the open. The only time the minimum daily temperatures reached less than $10{ }^{\circ} \mathrm{F}$ in the open occurred on one night in late January and once more in mid-February. Under the RC, the minimum daily temperatures remained several degrees $\left({ }^{\circ} \mathrm{F}\right)$ higher. On 26 Jan., the minimum temperature in the open was $4{ }^{\circ} \mathrm{F}$ and temperatures remained below $10^{\circ} \mathrm{F}$ for about $2 \mathrm{~h}$ in the open, but under the cover, it reached about $8^{\circ} \mathrm{F}$ and temperatures remained below $10{ }^{\circ} \mathrm{F}$ only for $10 \mathrm{~min}$. On 19 Feb., the temperatures dropped to below $10^{\circ} \mathrm{F}$ for $20 \mathrm{~min}$ in the open, but under the $\mathrm{RC}$, the lowest temperature recorded was $10.9^{\circ} \mathrm{F}$.

Results from the 27 Nov. 2006 artificial freezing test showed that the $\mathrm{LT}_{50}$ value was at $13^{\circ} \mathrm{F}$. By $31 \mathrm{Jan}$. 2007 , the $\mathrm{LT}_{50}$ had lowered to $0{ }^{\circ} \mathrm{F}$ for buds grown in the open, whereas that of buds on plants under RC was $\mathrm{l}^{\circ} \mathrm{F}$ (data not presented). The data suggest that the average maximum daily temperatures preceding collection (16-31 Jan.) being $9.7{ }^{\circ} \mathrm{F}$ warmer under $\mathrm{RC}$ than in the open had no effect on $\mathrm{LT}_{50}$ values. The $\mathrm{LT}_{50}$ values of buds of covered plants on 6 Mar. 2007 were at $6^{\circ} \mathrm{F}$. Because extensive cane and bud damage was observed on plants in the open by late February, freezing tests for canes in the open were not conducted.

Our study showed that floricanes of western trailing 'Siskiyou' blackberry plants in the open were severely damaged (Table 1). Cane and bud injury in covered plants was reduced and subsequent fruit yield was enhanced. Cane injury on plants under RC was much less than in the open, even after Winter 2004-05 


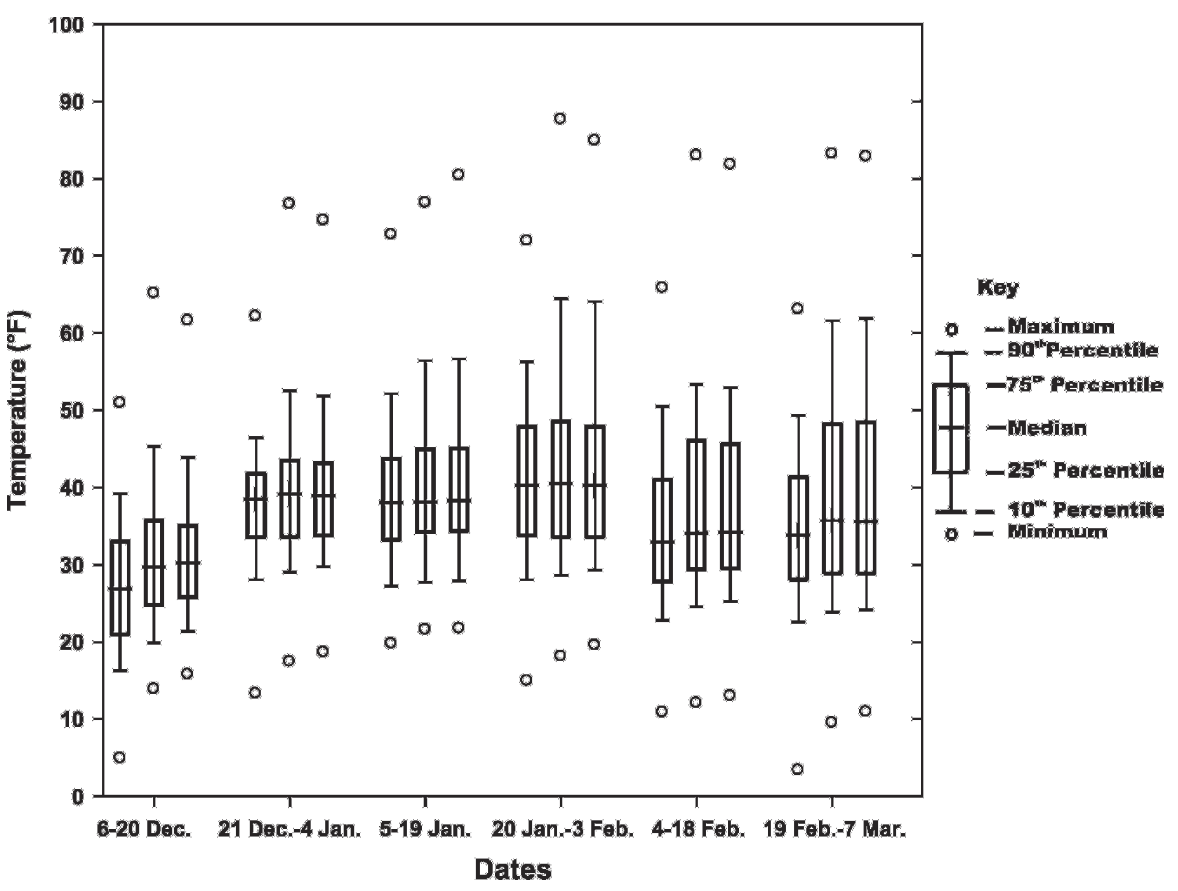

Fig. 6. Box-and-whisker plots showing the seasonality and extent of temperature variations in the open and under winter protection covers during Winter 2005-06. Top and bottom sides of the box represent the 75 th and 25 th percentiles of temperatures recorded for the period, respectively. Whiskers at the top and bottom of the box represent 90th and 10th percentiles of temperatures recorded for the period, respectively, and the circles at the top and bottom sides represent the maximum and minimum temperatures recorded for the period, respectively. Three plots in each period represent temperatures recorded in the open, under one layer of floating rowcover, and two layers of floating rowcover, respectively; $\left({ }^{\circ} \mathrm{F}-32\right) \div 1.8={ }^{\circ} \mathrm{C}$.

when temperatures dropped to below $10^{\circ} \mathrm{F}$ on several nights in Jan. 2005. Covered 'Siskiyou' plants that were low to the ground with one layer of RC produced 12 to $14 \mathrm{lb}$ of fruit per plant during this study. Covering plants with two layers of $\mathrm{RC}$ or $\mathrm{RC}+\mathrm{PE}$ did not significantly improve bud survival or increase yield compared with using one layer of RC. Fruit harvest of 'Siskiyou' started between 15 and 20 June each year of this study. During these years, first harvest dates of 'Apache', 'Triple Crown', and 'Chester Thornless' grown in the open at the same location were 1 July, 20 July, and 24 July, respectively (F. Takeda, unpublished data). Thus, fruit harvest of covered 'Siskiyou' trailing blackberry occurred several weeks earlier than erect and semierect thornless cultivars.

Wildung and Sargent (1989a, $1989 \mathrm{~b}$ ) studied the effect of snow cover on winter survival and productivity of blueberries in Minnesota where extremely cold winter temperatures $\left(-34^{\circ} \mathrm{F}\right)$ occur. They concluded that the value of $\mathrm{RC}$ in the were generally warmer and there were much larger day/night temperature fluctuations under the RC than in the open, and maximum temperatures under the $\mathrm{RC}$ reached well above $75^{\circ} \mathrm{F}$ on some days in December, January, and February (Figs. 4, 6, and 7). Although these periods of extremely high temperatures lasted less than $2 \mathrm{~h}$ per day as indicated by the 90th percentile temperatures being less than $62^{\circ} \mathrm{F}$, high mid-winter temperatures could contribute to deacclimation of buds and make buds more susceptible to freeze injury. Warmund et al. (1989) reported that blackberry buds exposed to $61^{\circ} \mathrm{F}$ for as few as 4 h deacclimated. Results of the artificial freezing tests performed in Winter 2006-07 indicated that $\mathrm{LT}_{50}$ values were $9^{\circ} \mathrm{F}$ on 27 Nov. 2006, before RC application, 0 and $1{ }^{\circ} \mathrm{F}$ for buds in the open and under RC, respectively, on 30 Jan. 2007, and $6{ }^{\circ} \mathrm{F}$ for buds under RC on 6 Mar. 2007 (data not presented). These findings suggest that the buds under $\mathrm{RC}$ and in the open had not deacclimated as of 31 Jan. However, by early March, extensive damage to buds and canes had occurred in plants in the open. Temperatures below $10{ }^{\circ} \mathrm{F}$ were recorded on 6 and 19 Feb. 2007 in the open. These events may have been lethal to the buds in the open. In contrast, the temperatures under the $\mathrm{RC}$ remained above $10{ }^{\circ} \mathrm{F}$ on these dates.

Other measured factors such as higher soil temperature and moisture content may improve tissue survival and yield in plants under RC. The difference in water vapor pressure between the plant surface and air is the driving force causing the movement of water vapor out of plants (Kramer, 1983). In our study, the differences in humidity between the air in the open and under RC were small at night (data not presented). During the day, humidity and temperature rose more quickly and remained higher under the cover than in the open. As a result, VPD was 100 to $250 \mathrm{kPa}$ higher under RC than in the open from December to March (Table 3). Extensive winter cane desiccation may occur when the air temperature rises above freezing and the vapor pressure gradient between plant surfaces and air steepens, causing more water vapor to move out of plants 
into the atmosphere (Kozlowski, 1976). In late fall, cane water content was about $69 \%$. Water content of canes under RC declined slightly in January and February and decreased to only $53 \%$ by 1 March. Water content of canes in the open remained similar to that of canes under RC until 6 Feb., but by 1 Mar., had decreased significantly to 28\%. Perhaps under RC treatment there was a means to replenish evaporative water loss into the atmosphere by conduction of water from the soil into the canes and evaporation of water at the soil surface. Soil temperatures in open plots were below $32^{\circ} \mathrm{F}$ and frozen over several weeks from late January to mid-February while under cover soil temperatures remained above the freezing point in 2005 (Fig. 5), and again in 2007 (data not presented). When the ground is frozen, water conduction is not possible from soil to aboveground plant parts.

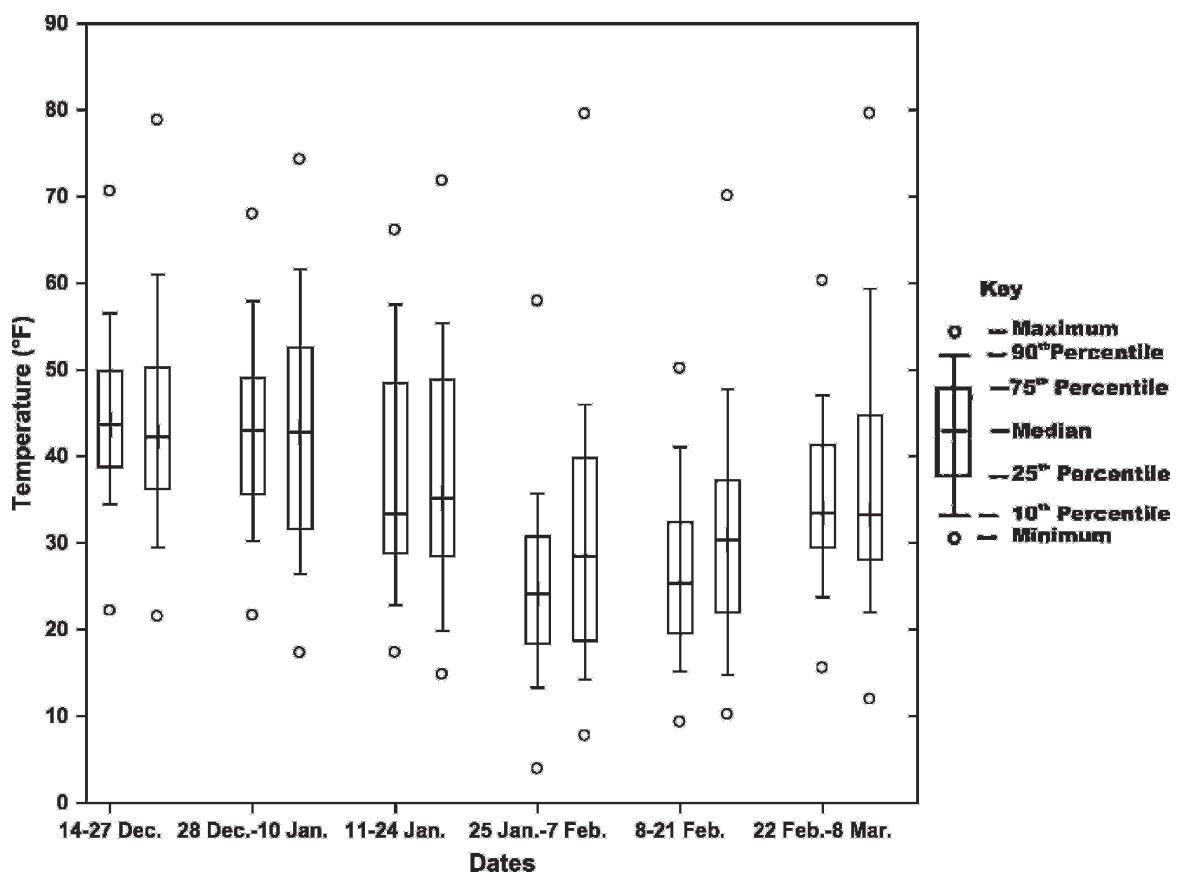

Fig. 7. Box-and-whisker plots showing the seasonality and extent of temperature variations in the open and under winter protection covers during Winter 2006-07. Top and bottom sides of the box represent the 75th and 25th percentiles of temperatures recorded for the period, respectively. Whiskers at the top and bottom of the box represent 90 th and 10 th percentiles of temperatures recorded for the period, respectively, and the circles at the top and bottom sides represent the maximum and minimum temperatures recorded for the period. Two plots in each period represent temperatures recorded in the open and under one layer of floating rowcover, respectively; $\left({ }^{\circ} \mathrm{F}-32\right) \div 1.8={ }^{\circ} \mathrm{C}$.

\section{Conclusions}

RC application in winter on 'Siskiyou' blackberry plants with all floricanes positioned close to the ground significantly reduced winter injury (Table 1). Winter protection elevated temperatures under the cover during the day and night under sunny conditions, with minimal differences during cloudy periods. Despite greater fluctuating temperatures under $\mathrm{RC}$ and $\mathrm{RC}+\mathrm{PE}$, 'Siskiyou' blackberry under cover suffered less winter injury compared with those plants in the open. Prolonged exposure to high daytime temperatures in midwinter could cause buds to de-harden (Brierley et al., 1952, Crandall, 1995, Warmund et al., 1989). However, we found that $\mathrm{LT}_{50}$ values for buds in the open and under cover remained similar from late November to January, although daytime temperatures under the cover were above $65^{\circ} \mathrm{F}$ on many days in January. A better understanding is needed on the de-hardening process and chill accumulation in plants that go through winters in which daytime temperatures reach as high as $85{ }^{\circ} \mathrm{F}$ and nighttime temperatures dip to $10^{\circ} \mathrm{F}$.

In the mid-Atlantic region, one layer of $\mathrm{RC}\left(\approx 1.5 \mathrm{oz} / \mathrm{yard}^{2}\right)$ provided sufficient winter protection for western trailing 'Siskiyou' blackberry. In this region, the planting of trailing cultivars with the use of RC during winter will make blackberry fruit available as early as mid-June. Although there is considerable research on protected cultivation techniques (Lamont, 2005; Pritts et al., 1999, Wells and Loy, 1985, and Wildung and Sargent, 1989b), much of the

Table 3. Effects of rowcover (RC) application on humidity, vapor pressure deficit (VPD), and cane water content. VPD was calculated from temperature and humidity recorded at 10-min intervals during daylight hours from 14 Dec. 2006 to 5 Mar. 2007. 'Siskiyou' blackberry plants were not covered (Open) or covered with one layer of rowcover (RC).

\begin{tabular}{|c|c|c|c|c|c|c|c|}
\hline \multirow[b]{2}{*}{ Variable } & \multirow[b]{2}{*}{ Treatment } & \multicolumn{6}{|c|}{ Date } \\
\hline & & $\begin{array}{c}1 \text { to } \\
30 \text { Nov. }\end{array}$ & $\begin{array}{c}14 \text { to } \\
31 \text { Dec. }\end{array}$ & $\begin{array}{c}1 \text { to } \\
15 \text { Jan. }\end{array}$ & $\begin{array}{l}16 \text { to } \\
31 \text { Jan. }\end{array}$ & $\begin{array}{c}1 \text { to } \\
15 \mathrm{Feb} .\end{array}$ & $\begin{array}{l}16 \text { Feb. } \\
\text { to } 5 \text { Mar. }\end{array}$ \\
\hline \multirow[t]{2}{*}{ Humidity (\%) } & Open & $-^{\mathrm{z}}$ & 68.9 & 68.2 & 54.8 & 62.7 & 56.9 \\
\hline & $\mathrm{RC}$ & - & 68.7 & 68.9 & 62.3 & 72.2 & 57.9 \\
\hline \multirow[t]{2}{*}{$\operatorname{VPD}(\mathrm{kPa})^{\mathrm{y}}$} & Open & - & $345 b^{x}$ & $345 \mathrm{~b}$ & $269 \mathrm{~b}$ & $197 \mathrm{~b}$ & $331 \mathrm{~b}$ \\
\hline & $\mathrm{RC}$ & - & $540 \mathrm{a}$ & $533 \mathrm{a}$ & 398 a & $286 \mathrm{a}$ & 589 a \\
\hline
\end{tabular}

${ }^{\mathrm{z}}$ Data not collected.

${ }^{\mathrm{y}} 1 \mathrm{kPa}=0.01$ bar.

${ }^{x}$ Means within a column for the variable listed and followed by the same letter are not significantly different at $P=0.05$.

${ }^{\mathrm{w}} \mathrm{Cane}$ water content determined on 20 Nov., 5 Jan., 17 Jan., 6 Feb., and 1 Mar. 
focus of previous research has been on the impact of different protection techniques on plant development and health, as well as the economic benefits of increased yield and season extension from elevating air and soil temperatures. However, little is known about internal water potential and winter injury as affected by different environmental parameters (air and soil temperatures, diurnal temperature fluctuations, mid-winter thaw followed by extremely low temperatures, and high solar radiation). This is due, in part, to the difficulty of acquiring reliable and relevant measurements. Formulas are available to determine the energy exchange rate for a protection system, but dynamic physiological models for integrating pertinent environmental parameters are needed to understand the benefits of RC in winter more fully for 'Siskiyou' and other blackberry cultivars.

Blackberry production in the mid-Atlantic region of the United States is not extensive because of adverse winter climatic conditions. However, RC will protect 'Siskiyou' canes from low temperature injury and will allow production of 'Siskiyou' blackberry in this area. Additionally, the use of the RCA trellis and RC would enhance the reliability of cropping at a relatively low cost $[\approx \$ 4000$ per acre for RCA trellising (R. Barnes, personal communication)], and an additional $\$ 3000$ per acre for RC. The use of RC for growing erect-type 'Apache' and 'Triple Crown' blackberries in areas further north (e.g., New York and the New England states) needs to be evaluated. A growing interest among locavores, food catering businesses, and regional grocers to use more fruit and vegetables produced locally (Sparks, 2008) should also encourage more blackberries to be produced in the eastern United States.

\section{Literature cited}

Bell, N., B. Strik, and L. Martin. 1995. Effect of date of primocane suppression on 'Marion' trailing blackberry. II. Cold hardiness. J. Amer. Soc. Hort. Sci. 120: 25-27.

Bittenbender, H.C. and G.D. Howell. 1974. Adaptation of the SpearmanKarber method for estimating the $\mathrm{T}_{50}$ of cold stressed flower buds. J. Amer. Soc. Hort. Sci. 99:187-190.
Brierley, W.G., R.H. Landon, and R.J. Stadtherr. 1952. The effect of daily alterations between 27 and 39 degrees F on retention or loss of cold resistance in the Latham raspberry. Proc. Amer. Soc. Hort. Sci. 59:173-176.

Clark, J.R. and J.N. Moore. 1999. 'Apache' thornless blackberry. HortScience 34:1291-1293.

Cortell, J.M. and B.C. Strik. 1997. Effect of floricane number in 'Marion' trailing blackberry. I. Primocane growth and cold hardiness. J. Amer. Soc. Hort. Sci. 122: 604-610.

Crandall, P.C. 1995. Bramble production: The production and marketing of raspberries and blackberries. Food Products Press, Binghamton, NY.

Brittingham-Brant, M., K. Demchak, M. Frazier, S.D. Guiser, J.M. Halbrendt, J.K. Harper, G. Krawczyk, K.M. Richards, E.S. Sánchez, J.W. Travis, B.A. Majek, P. Nitzsche, P. Oudemans, G. Pavlis, S. Polavarupu, D. Polk, P.R. Probasco, C. Rodriguez-Saona, W.J. Sciarappa, P.W. Shearer, M. Stanghellini, D.M. Caron, W.E. Kee, G.C. Johnson, B.R. Butler, J.A. Fiola, H.J. Swartz, A.D. Bratsch, J.F. Derr, J.A. Pattison, D.G. Pfieffer, K.S. Yoder, J.F. Baniecki, A. Biggs, H.W. Hogmire, R. Zimmerman, and E. Mashburn. 2006. The mid-Atlantic berry guide for commercial growers. Pennsylvania State Univ., College Agr. Sci. AGRS97.

Finn, C.E., F.J. Lawrence, B.C. Strik, B. Yorgey, and J. DeFrancesco. 1999. 'Siskiyou' trailing blackberry. HortScience 34:1288-1290.

Hanan, J.L. 1998. Greenhouses: Advanced technology for protected horticulture. CRC Press, Boca Raton, FL.

Harper, J.K., F. Takeda, and D.L. Peterson. 1999. Economic evaluation of improved mechanical harvesting systems for eastern thornless blackberries. Appl. Eng. Agr. 15(6):597-603.

Kozlowski, T.T. 1976. Water relations and tree improvement, p. 307-327. In: M. Cannell and F.T. Last (eds.). Tree physiology and yield improvement. Academic Press, London.

Kramer, P.J. 1983. Water relations of plants. Academic Press, New York.

Lamont W.J., Jr. 2005. Plastics: Modifying the microclimate for the production of vegetable crops. HortTechnology 15:477-481.

Pritts, M.P., R.W. Langhans, T.H. Whitlow, M.J. Kelly, and A. Roberts. 1999. Winter raspberry production in greenhouses. HortTechnology 9:13-15.
Richards, J.M. 1971. Simple expression for the saturation vapor pressure of water in the range of -50 to $140{ }^{\circ} \mathrm{C}$. Br. J. Appl. Physics 4:L15-L18.

Sparks, B.D. 2008. More than a new word. Amer. Fruit Grower 128(1):50.

Stiles, H.D. 1999. Limited arm-rotation shift-trellis (LARS) and primocane management apparatus (PMA) for raspberries and blackberries (Rubus cvs. or crops). Virginia Agr. Expt. Sta. (Blacksburg) Bul. Ser. 99-1.

Takeda, F. 1987. Some factors associated with fruit maturity range in cultivars of the semi-erect, tetraploid thornless blackberry. HortScience 22:405-408.

Takeda, F. 2008. Rotating cross-arm trellis system and cane training technique. 24 Apr. 2008. <http://www.trellisgrowing systems.com/resources/Rotating $\% 20$ Cross\%20Arm\%20Trellis\%20System.pdf>.

Takeda, F. and D.L. Peterson. 1999. Considerations for machine harvesting fresh-market eastern thornless blackberries: Trellis design, cane training systems, and mechanical harvester developments. HortTechnology 9:6-21.

Takeda, F., A.K. Hummell, and D.L. Peterson. 2003. Primocane growth in 'Chester Thornless' blackberry trained to the rotatable cross-arm trellis. HortScience 38:373-376.

U.S. Department of Agriculture. 2004. 2002 Census of agriculture: State data, Vol. 1. Table 33. Berries harvested for sale: 2002 and 1997, p. 496-499. 22 Dec. 2007. <http://www.usda.gov/census/ census02/volumel/us/st99_2_033.pdf>.

Warmund, M.R., M.F. George, M.R. Ellersiak, and J.V. Slater. 1989. Susceptibility of blackberry tissues to freezing injury after exposure to 16C. J. Amer. Soc. Hort. Sci. 114:795-800.

Warmund, M.R., F. Takeda, and G.A. Davis. 1992. Supercooling and extracellular ice formation in differentiating buds of eastern thornless blackberry. J. Amer. Soc. Hort. Sci. 117:941-945.

Wells, O.S. and J.B. Loy. 1985. Intensive vegetable production with row covers. HortScience 20:822-826.

Wildung, D.K. and K. Sargent. 1989a. The effect of snow depth on winter survival and productivity of Minnesota blueberries. Acta Hort. 241:232-237.

Wildung, D.K. and K. Sargent. 1989b. The effect of row covers on the winter survival and productivity of Minnesota blueberries. Acta Hort. 241:238-243. 